\title{
FISH ASSEMBLAGE STRUCTURE IN A FIRST ORDER STREAM, SOUTHEASTERN BRAZIL: LONGITUDINAL DISTRIBUTION, SEASONALITY, AND MICROHABITAT DIVERSITY
}

\author{
Lilian Casatti
}

Biota Neotropica v5 (n1) - http://www.biotaneotropica.org.br/v5n1/pt/abstract?article+BN02505012005

\author{
Date Received 07/27/2004 \\ Revised 11/21/2004 \\ Accepted 01/01/2005
}

UNESP - Universidade Estadual Paulista, Laboratório de Ictiologia, Departamento de Zoologia e Botânica, IBILCE (www.ibilce.unesp.br), Rua Cristóvão Colombo, 2265, 15054-000, São José do Rio Preto, SP, Brazil

(e-mail: lcasatti@ibilce.unesp.br)

\begin{abstract}
This study was carried out on a first order stream in the Morro do Diabo State Park, southeastern Brazil. Three equidistant stream stretches - upper, middle, and lower - were chosen for underwater observations and fish collections that were performed in the dry (June and September 2000) and wet seasons (December 2000 and March 2001). Of the 18 fish species documented, 11 were considered resident year round. Phalloceros caudimaculatus, Hypostomus nigromaculatus, Hisonotus francirochai, Trichomycterus diabolus, and Hypostomus ancistroides represented 90\% of the collected specimens. The highest richness and abundance occurred during the wet season. In general, the longitudinal addition of species follows the addition of microhabitats. Sexually mature individuals were present throughout the year for the majority of the species, which suggests broad reproductive activity. However, given that most juveniles specimens were collected during the wet season, it is hypothesized that reproduction and survival rates must be higher during this season due to higher availability of critical resources, most probably food and shelter.
\end{abstract}

Key words: Upper Rio Paraná, stream fishes, conservation, reproduction, river continuum concept.

\section{Resumo}

Este estudo foi conduzido em três trechos - superior, médio e inferior - de um riacho de primeira ordem no Parque Estadual Morro do Diabo, sudeste do Brasil. Observações subaquáticas a partir de mergulho livre e coletas foram realizadas na estação seca (junho e setembro de 2000) e chuvosa (dezembro de 2000 e março de 2001). Das 16 espécies documentadas, 11 foram residentes ao longo das observações. Phalloceros caudimaculatus, Hypostomus nigromaculatus, Hisonotus francirochai, Trichomycterus diabolus e Hypostomus ancistroides representaram $90 \%$ do total de indivíduos amostrados. A maior riqueza e abundância ocorreram durante a estação chuvosa. Em geral, a adição longitudinal de espécies seguiu a adição de micro-hábitats. Indivíduos sexualmente maduros foram encontrados ao longo do ano para a maioria das espécies, o que sugere prolongada atividade reprodutiva. Contudo, visto que a maioria dos jovens foi coletada na estação chuvosa, é provável que neste período ocorra um incremento de atividade reprodutiva, em razão de maior disponibilidade de recursos críticos, principalmente abrigos e alimentos.

Palavras-chave: Alto Rio Paraná, peixes de riachos, conservação, reprodução, conceito de contínuo fluvial. 


\section{Introduction}

The second most important drainage system within Brazil both in terms of area and diversity of its ichthyofauna is the Paraná-Paraguay-Uruguay system. Despite the great fish diversity documented for this basin (about 500 species), that ichthyofauna remains poorly known in many aspects and is furthermore endangered by several unsustainable anthropogenic activities (Menezes 1996). Although being less diverse than some other portions of the basin, the fish assemblages of the upper Rio Paraná basin, upriver of the Itaipu Reservoir, have suffered from the large scale environmental degradation that has taken place in that region. As a consequence, the original fish diversity in this basin cannot be assessed because a significant part of the original aquatic environments has been destroyed or significantly changed (Menezes 1996).

Castro \& Menezes (1998) have recorded, for the upper Rio Paraná basin in the State of São Paulo, 22 families and about 160 species of fishes. Contributing to this fauna are a number of small species that inhabit headwater streams that are characterized by high degrees of endemism, restricted geographic distributions, limited or no commercial value, dependence on riparian vegetation for food, reproduction, and shelter (Castro \& Menezes 1998). In the State of São Paulo the majority of the preserved streams are located in protected areas where it is possible to maintain the original features of the included water courses. Studies of the fish fauna in such areas are critical to document the primary characteristics of the original fish communities and thereby contribute to the delimitation of appropriate conservation areas and/or to recovery strategies for degraded streams of the upper Rio Paraná basin (Casatti et al. 2001). The present study, therefore, focused on the identification of the basic patterns of the organizational processes in the fish communities of a first order stream, Córrego São Carlos, that runs within the conservation area of the Morro do Diabo State Park, southeastern Brazil. The study is centered on the longitudinal distribution of the fish species in the stream and their distributions according to seasonality and microhabitat diversity.

\section{Study site}

The Morro do Diabo conservation area, created in 1941, is located in the Pontal do Paranapanema basin, município de Teodoro Sampaio, and is the most important forest fragment in the western portion of the State of São Paulo, Brazil (Clauset 1999). In 1986, that conservation area was converted to a State Park and currently includes 33,845 hectares (Clauset 1999). The vegetation is the mesophytic semi-deciduous forest with patches of cerrado, cerradão, and riparian vegetation (Schlittler et al. 1995). The climate in the region is humid subwarm tropical, with a dry season between April and September, and a wet season from October to March (Nimer 1989).
The Córrego São Carlos (also known as Córrego Taquara) is a first order stream (ranked in a 1:50,000 scale) which runs for about $5 \mathrm{~km}$ entirely inside the park, and it is a tributary of the Rio Paranapanema. Recently the mouth of this stream was impounded by the Rosana Reservoir. The upper reaches of the stream are characterized by riffles, that are progressively replaced downstream by pools and raceways. Three equidistant $100 \mathrm{~m}$ long stretches along the stream were chosen for underwater observations and sampling of the fish fauna (Table 1). The margins along the stream are slightly sinuous, with floodplain areas covered with grasses (mostly Commelinaceae and Poaceae) and pteridophytes (several Pteridaceae, Polypodiaceae, and Sellaginellaceae).

\section{Material and methods}

Field work included two samplings of the fish fauna during the dry season (June and September 2000) and two samplings during the wet season (December 2000 and March 2001). Water temperature, $\mathrm{pH}$, dissolved $\mathrm{O}_{2}$, and conductivity were recorded through digital equipment. Horizontal water transparency was measured with a Secchi disk while skin diving. Rainfall and air temperature data were provided by the Weather Station in the Morro do Diabo State Park, Teodoro Sampaio.

The collection methods of fishes was selected to maximize yield according to the physical characteristics of each stretch of the stream. In the upper stretch two sieves $(70 \mathrm{~cm}$ in diameter and $2.5 \mathrm{~mm}$ mesh) were placed close to the substrate, and the fishes were chased into the sieves over 40 minute period. In the middle and lower stretches of the stream two sieves were employed close to the banks and bottom (40 minutes), and a manual seine ( $2 \mathrm{~m}$ in length, $1.5 \mathrm{~m}$ in height and 2.5 $\mathrm{mm}$ mesh) was used in the raceways (20 minutes). Each stretch was blocked by a mesh net ( $2.5 \mathrm{~mm}$ mesh) at its upper end and the fishing operations progressed in an upstream direction. Fishes were immediately preserved in $10 \%$ formalin upon capture. The spatial distribution of the fish species in the middle and lower stretches of the stream was observed during 17 hours of snorkelling (13 diurnal and 4 nocturnal), according to the methods "focal animal” and "ad libitum" (Lehner 1998).

Species richness was estimated through ICE "Incidence-based Coverage Estimator" (Lee \& Chao 1994), which calculates the correction factor using the incidence (frequency of occurrence) of the rare species. Estimate of richness using ICE was processed through the software EstimateS 5 (Colwell 1997). Alpha diversity was calculated by the Shannon-Wiener $\left(\mathrm{H}^{\prime}\right)$ and Simpson (D) indexes and the evenness by the index of Pielou (e) (Ludwig \& Reynolds 1988). Statistical tests were processed utilizing the software BioEstat 2.0 (Ayres et al. 2000). Voucher specimens (LIRP 1128-1135, 1756-1662) were deposited in the Laboratório de Ictiologia de Ribeirão Preto (LIRP), Departamento de Biologia, Universidade de São Paulo, Brazil. 
Table 1. Physical, chemical, and environmental descriptors for each stretch of the Córrego São Carlos, Morro do Diabo State Park, São Paulo, Brazil, during the dry and wet seasons ( $\mathrm{nr}$, macrohabitat not registered).

\begin{tabular}{|c|c|c|c|c|c|c|}
\hline Parameters & \multicolumn{2}{|c|}{ Upper stretch } & \multicolumn{2}{|c|}{ Middle stretch } & \multicolumn{2}{|c|}{ Lower stretch } \\
\hline Coordinates & \multicolumn{2}{|c|}{$\begin{array}{c}22^{\circ} 35^{\prime} 280^{\prime \prime} \mathrm{S} \\
52^{\circ} 14^{\prime} 38.1 ” \mathrm{~W}\end{array}$} & \multicolumn{2}{|c|}{$\begin{array}{l}22^{\circ} 35^{\prime} 54.4^{\prime \prime} \mathrm{S} \\
52^{\circ} 14^{\prime} 45.2^{\prime \prime} \mathrm{W} \\
\end{array}$} & \multicolumn{2}{|c|}{$\begin{array}{c}22^{\circ} 36^{\prime} 23.8^{\prime \prime} \mathrm{S} \\
52^{\circ} 15^{\prime} 08.6^{\prime \prime} \mathrm{W} \\
\end{array}$} \\
\hline Altitude (m) & \multicolumn{2}{|c|}{294} & \multicolumn{2}{|c|}{286} & \multicolumn{2}{|c|}{284} \\
\hline & dry & wet & dry & wet & dry & wet \\
\hline Maximum depth (m) & 0.25 & 0.29 & 0.47 & 0.50 & 0.53 & 0.90 \\
\hline Range of width (m) & $0.8-2.6$ & $0.9-2.6$ & $0.9-3.6$ & $0.9-3.8$ & $1.4-3.7$ & $1.3-3.9$ \\
\hline Current - riffles $\left(\mathrm{m} \cdot \mathrm{s}^{-1}\right)$ & 1.50 & 1.50 & 0.34 & 0.35 & 0.66 & 0.70 \\
\hline Current - pools $\left(\mathrm{m}^{-\mathrm{s}^{-1}}\right)$ & $\mathrm{nr}$ & $\mathrm{nr}$ & 0.30 & 0.30 & 0.53 & 0.50 \\
\hline Water transparency (m) & 2.50 & 2.20 & 2.75 & 2.5 & 2.0 & 2.75 \\
\hline Water temperature $\left({ }^{\circ} \mathrm{C}\right)$ & 19.2 & 22.7 & 21.4 & 23.1 & 19.6 & 22.5 \\
\hline $\mathrm{pH}$ & 7.40 & 7.80 & 6.81 & 6.84 & 7.98 & 7.80 \\
\hline Dissolved $\mathrm{O}_{2}\left(\mathrm{mg} \cdot \mathrm{l}^{-1}\right)$ & 9.60 & 10.2 & 8.80 & 10.3 & 10.90 & 9.70 \\
\hline Conductivity $(\mu \mathrm{S})$ & 14.7 & 14.8 & 16.2 & 16.1 & 16.1 & 15.6 \\
\hline Bottom composition & \multicolumn{2}{|c|}{$\begin{array}{c}\text { mostly gravel, sand in } \\
\text { shallow pools along } \\
\text { banks }\end{array}$} & \multicolumn{2}{|c|}{$\begin{array}{c}\text { sand, gravel in small } \\
\text { riffles }\end{array}$} & \multicolumn{2}{|c|}{$\begin{array}{c}\text { sand, rare riffles, } \\
\text { many branches and } \\
\text { logs in pools }\end{array}$} \\
\hline
\end{tabular}

The reproductive stages of the specimens were determined through a macroscopical analysis of gonads. Four gonadal stages were identified: immature, maturing, mature, and empty (Vazzoler 1996) for all resident fish species. For the poeciliid Phalloceros caudimaculatus an additional stage was noted, that includes females with internal embryos (Machado et al. 2002). Size classes were defined according to the Sturges formulation (Silva \& Souza 1987) and juveniles of each species were those individuals included in the first three classes.

\section{Results}

\subsection{Environment}

The air temperature during the study period ranged from $-1.2^{\circ} \mathrm{C}$ (July 2000) to $37.8^{\circ} \mathrm{C}$ (October 2000). The monthly rainfall varied from $14.7 \mathrm{~mm}$ (May 2000) to $361 \mathrm{~mm}$ (December 2000). Physical and chemical variables registered for each stretch of stream are presented in Table 1.

\subsection{Ichthyofauna}

Eighteen fish species were collected (photographs of each species can be seen in Casatti et al. 2001), belonging to five orders and ten families (Table 2), for a total of 940 specimens and 1,671 g. Of these species, the orders Siluriformes (with nine species) and Characiformes (with six species) predominated. The majority of the individuals belong to the orders Siluriformes (66\%) and Cyprinodontiformes (28\%). The most common species in terms of number of individuals were Phalloceros caudimaculatus, Hypostomus nigromaculatus, Hisonotus francirochai, Trichomycterus diabolus, and Hypostomus ancistroides, in that order, which in sum represent $90 \%$ of the collected specimens.

During the wet season $63 \%$ of the collected specimens were obtained in contrast with the $37 \%$ collected during the dry season. The richness was also highest during the wet season (Table 3). The highest difference between observed and estimated richness occurred in the lower 
Family Erythrinidae

Hoplias malabaricus (Bloch, 1794)

Family Characidae

Astyanax altiparanae Garutti \& Britski, 2000

Astyanax sp.

Moenkhausia sanctaefilomenae (Steindachner, 1907)

Oligosarcus pintoi Campos, 1945

Family Crenuchidae

Characidium sp.

Family Pimelodidae

Imparfinis mirini Haseman, 1911

Phenacorhamdia tenebrosa (Schubart, 1964)

Rhamdia quelen (Quoy \& Gaimard, 1824)

Pimelodella aff. gracilis (Cuvier \& Valenciennes, 1840)

Family Trichomycteridae

Trichomycterus diabolus Bockmann, Casatti \& de Pinna, 2004

Family Loricariidae

Hisonotus francirochai (Ihering, 1928)

Hypostomus ancistroides (Ihering, 1911)

Hypostomus nigromaculatus (Schubart, 1964)

Family Callichthyidae

Corydoras aeneus (Gill, 1858)

Family Poeciliidae

Phalloceros caudimaculatus (Hensel, 1868)

Family Synbranchidae

Synbranchus marmoratus Bloch, 1795

Family Cichlidae

Crenicichla britskii Kullander, 1982 
Table 3. Fish species collected in each stretch of the Córrego São Carlos, Morro do Diabo State Park, São Paulo, Brazil, during the dry and wet seasons. ICE = incidence-based coverage estimator ( \pm standard error), $S L=$ range of standard length $(\mathrm{mm}), N=$ number of specimens, $B M=$ biomass.

Species:

\begin{tabular}{|c|c|c|c|c|c|}
\hline \multicolumn{3}{|c|}{ Dry season } & \multicolumn{3}{|c}{ Wet season } \\
\hline
\end{tabular}

\begin{tabular}{|l|c|c|c|c|c|c|}
\hline Upper stretch (6 species, ICE $=7 \pm 1.9$ ) & - & - & - & $41.5-119.1$ & 4 & 41.5 \\
\hline Rhamdia quelen $^{*}$ & $17.4-55.9$ & 36 & 25.5 & $21.0-60.6$ & 71 & 83.5 \\
\hline Trichomycterus diabolus * $^{*}$ & $30.3-35.1$ & 2 & 0.5 & - & - & - \\
\hline Hisonotus francirochai ** & 42.9 & 1 & 1.5 & 29.2 & 1 & 0.5 \\
\hline Hypostomus ancistroides * & $15.4-51.6$ & 76 & 62.5 & $13.8-65.0$ & 87 & 154.0 \\
\hline Hypostomus nigromaculatus * & $15.6-28.9$ & 12 & 3.0 & $15.6-27.1$ & 21 & 6.0 \\
\hline Phalloceros caudimaculatus * & & & & & &
\end{tabular}

Middle stretch $(9$ species, ICE $=10 \pm 4.0)$

\begin{tabular}{|l|c|c|c|c|c|c|}
\hline Oligosarcus pintoi $^{* *}$ & - & - & - & $74.4-88.6$ & 2 & 32.5 \\
\hline Rhamdia quelen $^{*}$ & $93.8-127.3$ & 7 & 92.0 & $32.2-105.2$ & 2 & 50.5 \\
\hline Trichomycterus diabolus $^{*}$ & $19.1-28.9$ & 5 & 1.5 & $26.9-59.9$ & 15 & 34.5 \\
\hline Hisonotus francirochai $^{*}$ & $26.3-37.1$ & 13 & 6.5 & $31.2-40.5$ & 10 & 31.0 \\
\hline Hypostomus ancistroides $*$ & $35.0-59.2$ & 7 & 23.5 & $15.4-63.6$ & 14 & 59.0 \\
\hline Hypostomus nigromaculatus * & $20.9-61.4$ & 11 & 25.5 & $18.1-52.5$ & 21 & 59.5 \\
\hline Corydoras aeneus $*$ & 30.2 & 1 & 1.5 & 23.2 & 1 & 1.5 \\
\hline Phalloceros caudimaculatus * & $11.8-30.6$ & 39 & 8.0 & $11.9-30.9$ & 96 & 45.5 \\
\hline Synbranchus marmoratus $*$ & - & - & - & 119.9 & 1 & 1.5 \\
\hline
\end{tabular}

Lower stretch (16 species, ICE $=21 \pm 3.0)$

\begin{tabular}{|c|c|c|c|c|c|c|}
\hline Hoplias malabaricus $* *$ & - & - & - & 72.8 & 1 & 9.0 \\
\hline Astyanax altiparanae * & $34.9-76.4$ & 4 & 27.5 & $23.3-75.5$ & 3 & 15.5 \\
\hline Astyanax sp. ** & 45.2 & 1 & 3.0 & - & - & - \\
\hline Moenkhausia sanctaefilomenae * & $51.3-60.5$ & 7 & 45.0 & $57.0-66.8$ & 7 & 61.0 \\
\hline Oligosarcus pintoi $*$ & $36.3-65.7$ & 12 & 9.0 & $23.9-75.2$ & 5 & 32.0 \\
\hline Characidium sp. $* *$ & - & - & - & 72.5 & 1 & 12.0 \\
\hline Imparfinis mirini $* *$ & $62.3-66.1$ & 2 & 8.5 & - & - & - \\
\hline Phenacorhamdia tenebrosa $* *$ & - & - & - & 44.1 & 1 & 0.5 \\
\hline Rhamdia quelen * & $85.6-108.0$ & 3 & 44.0 & 64.0 & 1 & 4.5 \\
\hline Pimelodella aff. gracilis ** & 79.2 & 1 & 7.0 & - & - & - \\
\hline Hisonotus francirochai $*$ & $11.7-38.4$ & 79 & 39.0 & $12.2-38.0$ & 62 & 33.0 \\
\hline Hypostomus ancistroides $*$ & $28.3-86.7$ & 29 & 142.0 & $15.3-97.8$ & 36 & 166.5 \\
\hline Hypostomus nigromaculatus * & $34.1-44.5$ & 4 & 8.0 & $32.8-45.3$ & 6 & 11.0 \\
\hline Corydoras aeneus * & $30.6-32.5$ & 7 & 12.0 & $30.7-45.2$ & 10 & 25.5 \\
\hline Phalloceros caudimaculatus * & $16.4-27.9$ & 11 & 3.0 & $9.6-28.0$ & 81 & 18.0 \\
\hline Crenicichla britskii $*$ & $38.3-41.5$ & 2 & 2.5 & $26.0-103.9$ & 8 & 79.5 \\
\hline Total & - & 372 & 602.0 & - & 568 & $1,069.0$ \\
\hline
\end{tabular}

* resident species

** non resident species 
Table 4. Diversity for each stretch of the Córrego São Carlos, Morro do Diabo State Park, São Paulo, Brazil, during the dry and wet seasons. $H^{\prime}=$ Shannon-Wiener index, $e=$ Pielou index of evenness, $D=$ Simpson index.

\begin{tabular}{lcccccc}
\hline & \multicolumn{2}{c}{ Upper stretch } & \multicolumn{2}{c}{ Middle stretch } & \multicolumn{2}{c}{ Lower stretch } \\
\cline { 2 - 6 } & dry & wet & dry & wet & dry & wet \\
\hline H' & 0.43 & 0.47 & 0.67 & 0.59 & 0.75 & 0.75 \\
e & 0.62 & 0.67 & 0.80 & 0.61 & 0.68 & 0.67 \\
D & 0.45 & 0.39 & 0.28 & 0.39 & 0.29 & 0.24 \\
\hline
\end{tabular}

stretch (16 species collected against 18 to 24 estimated species), that is from two to eight additional species (Table 3 ). Eleven species were resident (present in at least $50 \%$ of the collections, Dajoz 1978), with seven species recorded only once, mostly in the lower stretch of the stream. The lower stretch presented the highest diversity and evenness but few differences were observed along the seasons (Table 4).

\subsection{Reproduction and community structure}

All sampled species included individuals with gonads mature or maturing throughout the year. For the resident community as a whole, in June, September, and December, $47 \%$ of the collected individuals had gonads that were either mature or maturing whereas in March this proportion decreased to $38 \%$. Such a difference, however, is not significant (Incidence Test, $\mathrm{p}=0.3996$, $\mathrm{a}=0.01$ ). During the wet season $30 \%$ of the individuals were juveniles against $17 \%$ during the dry season and this difference is significant (Incidence test, $\mathrm{p}=0.0001$, á $=0.01$ ).

The community structure depicted below (see also Table 3) includes the 11 species considered resident. Whenever possible, observations about the reproductive stages are included.

Rhamdia quelen, $H$. francirochai, $H$. ancistroides, $H$. nigromaculatus, and $P$. caudimaculatus were found in all stretches of the stream. Rhamdia quelen (1 female : 1.6 male) was represented mostly by juveniles in the upper stretch during the wet season. In the middle and lower stretches it was represented mostly by males with gonads in maturation. Juveniles and adults of $H$. nigromaculatus (1:1) were progressively less abundant downstream and the smallest frequencies of mature individuals was obtained in September, at the end of the dry season. In contrast, $H$. ancistroides, $H$. francirochai, and $P$. caudimaculatus became more abundant downstream, most notably during the wet season. Contrary to $H$. nigromaculatus, at the end of the dry season $H$. ancistroides (1:1) and $H$. francirochai (12 females : 1 male) demonstrated the highest frequency of mature individuals. For P. caudimaculatus ( 4 females : 1 male), at least $80 \%$ of the individuals in each collection were mature or had embryos, indicating continuous reproduction throughout the year.

Trichomycterus diabolus $(1: 1)$ was present in the upper and middle stretches during all seasons and was represented by juveniles and adults. The smallest frequencies of mature individuals was obtained in September at the end of the dry season, the same situation found in H. nigromaculatus.

Oligosarcus pintoi and Corydoras aeneus were present in the middle and lower stretches but were more common in the lower stretch. Although mature males and females of $O$. pintoi (1:1) were present throughout the year, juveniles were collected only during the wet season. In the case of $C$. aeneus (3 females : 1 male) although a higher proportion of mature individuals was obtained in December, no juveniles were collected.

Astyanax altiparanae, Moenkhausia sanctaefilomenae, and Crenicichla britskii were present solely in the lower stretch of the stream. Astyanax altiparanae and M. sanctaefilomenae were represented mainly by mature males. Crenicichla britskii was represented by few mature individuals (only 1 female, and 1 male) in December and by juveniles in March and June.

\section{Discussion}

\subsection{Ichthyofauna}

The taxonomic predominance of the orders Siluriformes and Characiformes in the Córrego São Carlos agrees with the expected ichthyofaunistical composition for non-estuarine rivers in the Neotropical region (Lowe-McConnell 1987), but the noteworthy abundance of the order Siluriformes may be correlated with habitat characteristics, specifically with the predominance of riffle areas in the upper stretch and submerged marginal vegetation in the middle and lower stretches of the stream (see item 5.3). Diversity indexes indicate the dominance of a few species in the upper stretch and the higher occurrence of rare species in the lower stretches (Ludwig \& Reynolds 1988). The highest difference between observed and estimated richness in the lower stretch probably is due to the presence of many rare species in the sample when compared to the other stretches. 


\subsection{Seasonality}

Upstream areas are hypothesized to demonstrate less structured assemblages due to abrupt seasonal changes, whereas downstream sites would have higher stability due to the larger catchment area and the consequent reduction of disturbing hydraulic effects (Horwitz 1978, Peres-Neto et al. 1995). In fact, some streams, particularly those located on the slopes are strongly disturbed as a consequence of seasonal variations in water flow (Caramaschi 1986). The hydraulic condition found in the Córrego São Carlos was quite uniform along the collections, with minimal changes detected between the seasons. Such uniformity is probably related to local features which reduce the likelihood of occurrence of flash floods, most notably the dense forest coverage, the slight topography, the absence of upstream tributaries, and the sandy soil (Suguio \& Bigarella 1990). This relative stability is evidenced by the water transparency and physiochemical features, as well as in the fish diet (Casatti 2002).

Despite the relative environmental stability cited above for the Córrego São Carlos, neither the fish abundance nor richness were stable throughout the year, with higher values obtained during the wet season. In general, in Neotropical regions the increase of diversity and richness during the wet season is associated with the recruitment from adjacent areas or with the beginning of the reproductive cycle (Lowe-McConnell 1987, see Garutti 1988 for an example in the upper Rio Paraná basin). Because the studied stream lacks tributaries, fish recruitment from upper areas during the wet season did not affect the resident fish community. Downstream recruitment also seems to be scarce as evidenced by several collection efforts in the mouth of the Córrego São Carlos in the Rosana Reservoir, where only six species (Hoplias malabaricus, A. altiparanae, O. pintoi, H. ancistroides, Synbranchus marmoratus, and C. britskii) were observed, each represented by only a few specimens (Casatti et al. 2003).

The occurrence of sexually mature individuals throughout the year for most species should result in relatively constant proportions of juveniles collected in those populations. However, a significantly higher number of juveniles were found during the wet season. The interpretation for this apparent disparity is that, despite the continuous recruitment of juveniles throughout the year, a well documented life-history strategy for headwater stream fishes (Schlosser 1982, Garutti 1989), the reproduction must be increased and the mortality rate should be smaller during the wet season probably due to a higher availability of critical resources (food and shelter probably). The pattern of higher food availability and shelter during the wet season is cited both for temperate (Schlosser 1982) and tropical streams (Angermeier \& Karr 1983, Lowe-McConnell 1987). Thus, in the studied stream reproduction throughout the year with the hypothesized higher reproduction and juveniles survival rates during the wet season should play an important factor in the maintenance of the fish community.

\subsection{Longitudinal distribution and microhabitat- related diversity}

The addition of species is the main apparent process shaping the longitudinal distribution of the ichthyofauna in the Córrego São Carlos. In several temperate U.S. drainages, Horwitz (1978) verified primarily addition process for 15 streams, including diversity increases from headwaters to stream mouth. In a stream in the upper Rio Paraná basin, Brazil, the longitudinal addition of species also was observed by Garutti (1988) and was considered the main succession process acting in tropical streams characterized by slight topography (Caramaschi 1986).

It is well known that substrate, depth and current are some of the most important physical features determining the distribution of fishes in stream communities (Sheldon 1968, Gorman \& Karr 1978, Schlosser 1982, Angermeier \& Karr 1983, Angermeier \& Schlosser 1989) and the combination of such environmental features, producing a mosaic of microhabitats can explain the downstream increase in species richness (Gorman \& Karr 1978). In the Córrego São Carlos, downstream addition of species seems to be closely related with the progressive increase in microhabitat diversity.

In the upper stretch, the shallower depth, the substrate composed of gravel and pebbles and the strong current seems to represent favorable conditions for T. diabolus and $H$. nigromaculatus, the most abundant species in this stretch of the stream, but which are progressively less frequent in the middle and lower stretches. It is noteworthy that $R$. quelen was represented by juveniles (41.5-119.1 mm $\mathrm{SL}$ ) found just during the wet season, suggesting that the upper stretch may be used as a rearing area for sub-adults of this species.

In the middle stretch, despite being deeper than the upper one, the habitat volume is still reduced for the active swimmers, such as the characins. The flooded margins covered by grasses are important microhabitats for $H$. francirochai, that is also very abundant in the lower stretch. A strong relationship with the submerged marginal vegetation was also observed for other species of the Hypoptopomatinae in Brazil (Costa 1987, Casatti \& Castro 1998).

In the middle and lower stretches the bottom is mostly sandy, with small pools along the banks. This microhabitat is occupied by C.aeneus, that occurs in groups of six to ten individuals. A similar spatial occupation for this species was reported by Aranha et al. (1993) in the Rio Alambari, southeastern Brazil. 
In the lower stretch the depth notably allows the presence of the active swimmers, such as $A$. altiparanae, that is frequently found in groups of 20 to 30 individuals. Abundant woody debris is used by $H$. ancistroides. The role of woody debris for fishes, including protection from current, food availability or camouflage from predators, was discussed by Angermeier \& Karr (1984). The marginal pools in association with submerged roots of the riparian vegetation are broadly occupied by $C$. britskii. In a stream in the central portions of Amazonia, Sabino \& Zuanon (1998) observed C. notophthalmus and Crenicichla sp. occupying marginal backwaters in which they were ambush preys.

One of the most important theories about organization of riverine ecosystems is the River Continuum Concept (RCC, Vannote et al. 1980). This theory states that rivers represent physical gradients, where the sub-systems are linked longitudinally along the continuum, and the distribution of organisms is established in order to conform to the physical conditions of the channel (Peres-Neto et al. 1995).

In the Córrego São Carlos, the longitudinal species addition followed a continuum of microhabitat addition. In the upper stretch the riffles and shallow marginal ponds are predominant, being gradually supplemented by marginal grasses in the middle stretch and by the deep pools, with litter, logs, and submerged branches in the lower stretch. Such an increase in habitat complexity supports a higher number of species which are able to explore different niches (Lowe-McConnell 1987). The longitudinal addition of fish species associated with the increase of microhabitat diversity in this first order stream is consistent with the qualitative predictions of the RCC.

Finally, understanding life-history and behavioral ecology of fish species may be helpful to management and conservation populations of freshwater fish populations in fragile areas as demonstrated in many studies (for a revision, see Vincent \& Sadovy 1998; for an example in Neotropical area, see Sabino \& Andrade 2003).

\section{Acknowledgements}

I thank Hertz F. Santos, Katiane M. Ferreira, Luiz S. F. Martins, Renata Stopiglia, and Humberto F. Mendes for help during field work; Francisco Langeani for help with the identification of fish species; Heraldo A. Britski and Júlio C. Garavello for identification of Hisonotus francirochai; Ricardo M.C. Castro for supervision; Instituto Florestal-SP, Morro do Diabo State Park, and Departamento de Biologia FFCLRP-USP for facilities; IBAMA for collecting permission; Jansen A. Zuanon, Donald Stewart, and Richard P. Vari for comments on improving the manuscript. This work was supported by the State of São Paulo Research Foundation (FAPESP) within the BIOTA/ FAPESP Program - O Instituto Virtual da Biodiversidade (www.biota.org.br) - through the Thematic Project "Fish Diversity of the Headwaters and Streams of the Upper Paraná
River System in State of São Paulo, Brazil" (98/05072-8, 00/ 01919-8, 01/13340-7, 02/05996-2) and by PRONEX Project (661058/1997-2). Author receives grant from FAPESP (01/ 13340-7,02/05996-2).

\section{References}

ANGERMEIER, P.L. \& KARR, J.R. 1983. Fish communities along environmental gradients in a system of tropical streams. Env. Biol. Fish. 9:117-135.

ANGERMEIER, P.L. \& KARR, J.R. 1984. Relationships between woody debris and fish habitat in a small warmwater stream. Trans. Am. Fish. Soc. 113:716-726.

ANGERMEIER, P.L. \& SCHLOSSER, I.J. 1989. Species-area relationships for stream fishes. Ecology 70:1450-1462.

ARANHA, J.M.R., CARAMASCHI, E.P. \& CARAMASCHI, U. 1993. Ocupação espacial, alimentação e época reprodutiva de duas espécies de Corydoras Lacépède (Siluroidei, Callichthyidae) coexistentes no Rio Alambari (Botucatu, São Paulo). Revta bras. Zool. 10:453-466.

AYRES, M., AYRES Jr., M. ,AYRES, D.L. \& SANTOS, A.A.S. 2000. BioEstat. Aplicações estatísticas nas áreas das ciências biológicas e médicas. Software, version 2.0. Sociedade Civil Mamirauá, Belém, Brazil.

CARAMASCHI, E.P. 1986. Distribuição da ictiofauna de riachos das bacias do Tietê e do Paranapanema, junto ao divisor de águas (Botucatu, SP). Tese de Doutorado, Universidade Federal de São Carlos, São Carlos.

CASATTI, L. 2002. Alimentação dos peixes em um riacho do Parque Estadual Morro do Diabo, bacia do Alto Rio Paraná, sudeste do Brasil. Biota Neotropica 2: http:// www.biotaneotropica.org.br/v2n2/pt/abstract?article+ BN02502022002.

CASATTI, L. \& CASTRO, R.M.C. 1998. A fish community of the São Francisco River headwaters riffles, southeastern Brazil. Ichthyol. Explor. Freshwaters 9:229-242.

CASATTI,L., LANGEANI, F. \& CASTRO, R.M.C. 2001.Peixes de riacho do Parque Estadual Morro do Diabo, bacia do Alto rio Paraná, SP. Biota Neotropica 1: http:// www.biotaneotropica.org.br/v2n2/pt/abstract?inventory+ BN00201122001.

CASATTI,L., MENDES, H.F. \& FERREIRA, K.M. 2003. Aquatic macrophytes as feeding site for small fishes in the Rosana Reservoir, Paranapanema River, southeastern Brazil. Braz. J. Biol. 62:1-8.

CASTRO, R.M.C. 1999. Evolução da ictiofauna de riachos sul-americanos: padrões gerais e possíveis processos causais. In Ecologia de Peixes de Riachos: Estado Atual e Perspectivas (E.P. Caramaschi, R. Mazzoni, C.R.S.F. Bizerril, P.R. Peres-Neto, eds.). Oecologia Brasiliensis, v. VI, PPGEUFRJ, Rio de Janeiro, p. 139-155.

CASTRO, R.M.C. \& MENEZES, N.A. 1998. Estudo diagnóstico da diversidade de peixes do Estado de São Paulo. In Biodiversidade do Estado de São Paulo, Brasil: Síntese do conhecimento ao final do século XX, 6: vertebrados (R.M.C. Castro, ed.). WinnerGraph, São Paulo, p. 1-13. 
CLAUSET, L.R. 1999. Paisagem paulista: áreas protegidas. Empresa das Artes, São Paulo.

COLWELL, R.K. 1997. EstimateS 5. Statistical estimation of species richness and shared species from samples. Software, version 5.0.1. University of Connecticut, USA.

COSTA, W.J.E.M. 1987. Feeding habits of a fish community in a tropical coastal stream, rio Mato Grosso, Brazil. Stud. Neotrop. Fauna \& Environm. 22:145-153.

DAJOZ, R. 1983. Ecologia geral. Ed. Vozes, São Paulo.

GARUTTI, V. 1988. Distribuição longitudinal da ictiofauna de um córrego na região noroeste do Estado de São Paulo, Bacia do Rio Paraná. Rev. Brasil. Biol. 48:747-759.

GARUTTI, V. 1989. Contribuição ao conhecimento reprodutivo de Astyanax bimaculatus (Ostariophysi, Characidae), em cursos de água da bacia do Rio Paraná. Rev. Brasil. Biol. 49:489-495.

GORMAN, O.T. \& KARR, J.R. 1978. Habitat structure and stream fish communities. Ecology 59:507-515.

HORWITZ, R.J. 1978. Temporal variability patterns and the distributional patterns of stream fishes. Ecol. Monogr. 48:307-321.

LEE, S.M. \& CHAO, A. 1994. Estimating population size via sample coverage for closed capture-recapture models. Biometrics 50:88-97.

LEHNER, P.N. 1998. Handbook of ethological methods. Garland STPM Press, London.

LOWE-McCONNELL, R.H. 1987. Ecological studies in tropical fish communities. Cambridge University, Cambridge.

LUDWIG, J.A. \& REYNOLDS, J.F. 1988. Statistical ecology: a primer on methods and computing. Wiley, New York.

MACHADO, G., GIARETTA,A.A. \& FACURE, K.G. 2002. Reproductive cycle of a population of the guaru, Phalloceros caudimaculatus (Poeciliidae), in Southeastern Brazil. Stud. Neotrop. Fauna Environ. 37:15-18.

MENEZES, N.A. 1996. Methods for assessing freshwater fish diversity. In Biodiversity in Brazil (C.E.M. Bicudo \& N.A. Menezes, eds.). CNPq, São Paulo, p. 289-295.

NIMER, E. 1989. Climatologia do Brasil. Secretaria de Planejamento e Coordenação da Presidência da República e IBGE, Rio de Janeiro.

PERES-NETO, P.R., BIZERRIL, C.R.S.F.\& IGLESIAS, R. 1995. An overview of some aspects of river ecology: a case study on fish assemblages distribution in an eastern Brazilian Coastal River. In: Estrutura, funcionamento e manejo de ecossistemas brasileiros (F.A. Esteves, ed.). Oecologia Brasiliensis, v. I, PPGE-UFRJ, Rio de Janeiro, p. 317-334.

SABINO, J. \& ANDRADE, L.P. 2003. Uso e conservação da ictiofauna na região de Bonito, Mato Grosso do Sul: o mito da sustentabilidade ecológica no rio Baía Bonita (Aquário Natural de Bonito). Biota Neotropica 3: -http:// www.biotaneotropica.org.br/v3n2/pt/download?point-ofview+BN00403022003+item.

SABINO, J. \& ZUANON, J. 1998. A stream fish assemblage in Central Amazonia: distribution, activity patterns and feeding behavior. Ichthyol. Explor. Freswaters 8:201-210.
SCHLITTLER, F.H.M., DEMARINIS, G. \& CESAR, O. 1995. Estudos fitossociológicos na floresta do Morro do Diabo (Pontal do Paranapanema, SP), Brasil. Arq. Biol. Tecnol. 38:217-234.

SCHLOSSER, I.J. 1982. Fish community structure and function along two habitat gradients in a headwater stream. Ecol. Monogr. 52:395-414.

SHELDON, A.L. 1968. Species diversity and longitudinal succession in stream fishes. Ecology 49:193-198.

SILVA, J.X. \& SOUZA, M.J.L. 1987. Análise ambiental. Universidade Federal do Rio de Janeiro, Ed. Abreu e Associada, Rio de Janeiro.

SUGUIO, K. \& BIGARELLA, J.J. 1990. Ambientes fluviais. Editora UFPR, Curitiba.

VANNOTE, R.L., MINSHALL, G.W., CUMMINS, K.W., SEDELL, J.R. \& CUSHING C.E. 1980. The river continuum concept. Can. J. Fish. Aquat. Sci. 37:130-137.

VAZZOLER,A.E.A.M. 1996. Biologia da reprodução de peixes teleósteos. Eduem, Maringá.

VINCENT, A. \& SADOVY, Y. 1998. Reproductive ecology in the conservation and management of fishes. In: Behavioral ecology and conservation biology (T. Caro, ed.). Oxford University Press. Oxford, p. 209-245.

Title: Fish assemblage structure in a first order stream, southeastern Brazil: longitudinal distribution, seasonality, and microhabitat diversity

Authors: Lilian Casatti

Biota Neotropica, Vol. 5 ( number 1): 2005

http://www.biotaneotropica.org.br/v 5n 1/pt/ abstract?article+BN02505012005

Recebido: 27/07/2004- Revisado: 21/11/2004

Publicado: 01/01/2005-ISSN 1676-0611 